\title{
Academic inbreeding and publication activities of Russian faculty
}

\author{
Olga Alipova \\ Center for Institutional Studies, National Research University Higher School of \\ Economics, Moscow, Russia \\ Andrey Lovakov \\ Center for Institutional Studies, National Research University Higher School of \\ Economics, Moscow, Russia
}

\section{In press}

Tertiary Education and Management

DOI: $10.1080 / 13583883.2017 .1395905$

Corresponding author: Andrey Lovakov. Center for Institutional Studies, National Research University Higher School of Economics, lovakov@ hse.ru

\section{Funding}

The article was prepared within the framework of the Basic Research Program at the National Research University Higher School of Economics (HSE), and supported within the framework of a subsidy by the Russian Academic Excellence Project '5-100'. 
The literature on the consequences of academic inbreeding shows ambiguous results: some papers show that inbreeding positively influences research productivity measured by the quantity and quality of publications, while others demonstrate the opposite effect. There are contradictory results both in the studies of different countries and within countries. This variety of results makes it impossible to transfer the findings from one academic system to another, and in Russia this problem has been underexplored. This paper focuses on the relationship between inbreeding and publication activity among Russian faculty. The research was conducted using the data from the 'Monitoring of educational markets and organizations' survey. The results show that there is no significant effect of academic inbreeding on publication productivity: no substantial and robust differences in publication activity between inbreds and noninbred have been found. The paper finishes with the discussion of possible explanations inherent in the Russian academic system.

Keywords: academic profession; academic inbreeding; publication activity; faculty; Russian higher education

\section{Introduction}

In the modern world academic mobility (i.e. the change of workplace or affiliations by an academic) is generally regarded as a highly desirable phenomenon. It is believed that mobility enhances social capital of faculty, facilitates knowledge circulation and helps academic staff to broaden their outlook (Bäker, 2015; Horta, Veloso, \& Grediaga, 2010; Pelz \& Andrews, 1966). Mobile academics usually have better collaboration opportunities, which may positively affect their publishing productivity. This is regarded as one of the main indicators of the professional success of an academic affecting their promotion, salary, prospects of research funding, and recognition (Fox, 1983). Thus, there is a commonly accepted opinion that academic mobility leads to positive consequences both for individual academics, academic units, institutions and systems as a whole (Fernández-Zubieta, Geuna, \& Lawson, 2015). 
Academic inbreeding understood as the practice of hiring university's own graduates, is opposite to mobility and, on the contrary, is usually regarded as a negative phenomenon. Harvard President Charles Eliot, who was the first to draw attention to inbreeding, mentioned it in his speech as an unwise practice (Eliot, 1908). Since that first allusion a generally negative perception of inbreeding has become established in the literature and among policymakers (Gorelova \& Yudkevich, 2015). There is an almost unanimous consent that inbreeding is a harmful practice at both national and institutional levels, and that it leads to knowledge stagnation, as inbreds usually reproduce the ideas of their teachers, lack a broader outlook, have smaller social capital and, therefore, fewer collaboration opportunities (Horta et al., 2010). There is empirical evidence that the higher level of inbreeding in the academic department or even in the whole country, the lower their publication productivity is (Inanc \& Tuncer, 2011; Morichika \& Shibayama, 2015; Soler, 2001). Policymakers in many countries try to eliminate or even prohibit the detrimental practice of inbreeding at both institutional and national levels. For instance, in Germany and the USA there are formal and informal regulations forbidding universities to hire their own graduates at certain positions (Musselin, 2004; Pan, 1993).

At the same time, empirical studies at the individual level show that the consequences of inbreeding are not so unambiguous: some papers show that inbreeding is positively related to research productivity, time management and academic communication of faculty (e.g. Klemenčič \& Zgaga, 2015 (Slovenia); McGee, 1960 (USA); Wyer \& Conrad, 1984 (USA)), others demonstrate that there is a negative correlation between faculty inbreeding status and their productivity (Dutton, 1980 (USA); Eells \& Cleveland, 1935 (USA); Hargens \& Farr, 1973 (USA); Horta, 2013 (Portugal); Horta et al., 2010 (Mexico)), or that there is no statistical difference between inbreds and non-inbreds at all (Cruz-Castro \& Sanz-Menéndez, 2010 (Spain); Pan, 1993 (USA); Roleda, Bombongan, Tan, Roleda, \& Culaba, 2014 
(Phillippines); Sato, 1992 (USA); Smyth \& Mishra, 2014 (Australia); Sologub \& Coupé, 2015 (Ukraine)). The results differ significantly not only between countries, but also between research works within the same country across time. Insofar as possibilities for academic mobility depend heavily on peculiarities of the academic labor market (Altbach, Yudkevich, \& Rumbley, 2015a, 2015b; Horta \& Yudkevich, 2016; E. Sivak \& Yudkevich, 2008), this may affect the consequences of both academic mobility and academic inbreeding. That is why, it is important to evaluate the effects of these two practices within the context of the academic system existing in the country during the period of research to understand clearly the impact of these practices.

This study focuses on the relationship between inbreeding and publication activity in the context of the Russian academic system. The paper provides the first multivariate, systematic study of academic inbreeding and publication activity in Russia based on a national sample. The practice of academic inbreeding is widespread in the country (64\% of faculty in Russia are employed by their university of graduation, according to 'Changing Academic Profession' data (Yudkevich, Kozmina, Sivak, Bain, \& Davydova, 2013)). Nevertheless, this phenomenon and its consequences have been sparsely investigated, with only qualitative studies and case studies available (Horta \& Yudkevich, 2016; E. Sivak \& Yudkevich, 2015; Y. Sivak \& Yudkevich, 2009). It is especially important and interesting to evaluate the consequences of academic inbreeding in Russian academia, especially in view of contemporary reforms. Today, the Russian academic system is in a transition period, pressured by the necessity to improve the competitiveness and positions of Russian universities in global university rankings. For this purpose, several reforms of Russian higher education have been introduced in recent years. Among them are 1) the establishment of 'National Research University' status in 2008; 2) the introduction of 'incentive contracts' for university staff in 2012; and 3) the launch of the Program for the Improvement of Global 
Competitiveness, 'Project 5-100' (aimed at securing the entrance of at least 5 Russian universities into the top-100 global university rankings by 2020) (Yudkevich, 2014). These reforms concern the academic profession as a whole and its different aspects. Particular attention is given to the research productivity of university faculty, which is regarded as an important criterion by all the global university rankings. Moreover, further reforms are aimed specifically at the improvement of the number of Russian publications and their citations in international citation databases Web of Science and Scopus (Presidential decree No 599, from 7 May 2012). All these reforms force Russian faculty to publish more actively, both in international and domestic outlets, though for many decades the academic profession in Russian higher education institutions has been mostly teaching oriented (Yudkevich, 2014). These reforms apply pressure on, primarily, quantitative performance, paying much less attention to qualitative performance, which may result in the popularization of unfair publication practices, such as publishing in predatory journals (Sterligov \& Savina, 2016). At the same time, current changes also force universities to struggle for the most efficient and successful faculty, and they may influence some personnel decisions, including inbreeding and mobility issues. Thus, Russian faculty now have to work in a constantly changing environment, becoming increasingly competitive, and it is very interesting to observe how this situation affects the relationship between academic inbreeding and the publishing productivity of faculty. The results contribute to the understanding of the consequences of widespread inbreeding in Russia and may help to adjust university hiring policies to increase the productivity of university faculty. 


\section{Data and method}

\section{Data}

The empirical analysis was based on the data from the survey entitled 'Monitoring of educational markets and organizations' (MEMO) (https://memo.hse.ru/en/) for 2016. This survey has been conducted annually since 2002 by the Higher School of Economics at the initiative and with the support of the Ministry of Education and Science of the Russian Federation with the purpose of collecting generalized information and micro data, analysing, generalizing and presenting information on recent trends in education in Russia. The project covers practically all levels of education - pre-schooling, schooling, professional, and tertiary - and is aimed at surveying pupils/students, teachers and academics, and heads of organizations. The MEMO embraces both public higher education institutions subordinated to the Ministry of Education and Science, and their private counterparts, although it excludes medical and military institutions. This study used data from the higher education institutions faculty survey collected in 2016. The data contains the information on 1559 respondents from 100 higher education institutions situated in 34 Russian regions. The sample for the survey was double stratified. At the first stage, higher education institutions were selected based on their geographical location and their participation in previous waves (the panel study of organizations is supported). The second stage involved the selection of faculty. About 15-20 respondents were surveyed in each institution. One of the additional conditions for the research was that it be obligatory to survey faculty in those higher education institutions where students were surveyed (the student sample was also double stratified), although it could also include other universities. The survey was arranged as academics independently filling in paper questionnaires.

According to the methodology of the MEMO faculty survey, the sample was representative and the marginal sample error was $2.5 \%$. Nevertheless, our empirical check of 
sample representativeness, carried out by comparing the distribution of some characteristics of academics (gender, age, academic rank, academic degree) in the sample with the distribution of those characteristics in the general population (Bondarenko et al., 2017), showed that there were some small biases (see Table 1). The MEMO-2016 sample was slightly biased towards middle-aged, junior ranking faculty not holding academic degrees, and it slightly underestimated the share of holders of doctorates and older academics, those aged over 60 . The sample was completely representative by gender and provided precise estimates of $\mathrm{PhD}$ holders. Because in our paper we aim at studying the phenomenon of academic inbreeding, the most important characteristic in terms of representativeness was the inbreeding rate. Unfortunately, we cannot conclude how representative the sample was from this point of view, as no official, non-self-reported data for the average inbreeding rate of Russian faculty exist. The biases we observed may be due to the research design, as discussed above, and because the MEMO survey excluded medical institutions' faculty and comprised only a very small proportion of private universities in Russia. Moreover, faculty in Russia are usually regarded as a group that is hard to research, as most universities discourage sociological surveys of their personnel and it is rather difficult to get completely representative samples of Russian academics. Nevertheless, the procedure for sample construction is reliable and maximally approximated to the simple random sample; thus, we consider that the survey data are appropriate for our study. 
Table 1. Representativeness assessment.

\begin{tabular}{|c|c|c|c|c|c|c|c|c|c|c|}
\hline & \multicolumn{2}{|c|}{ All HEIs in Russia } & \multicolumn{4}{|c|}{ MEMO-2016 } & \multicolumn{4}{|c|}{ Research sample } \\
\hline & $\begin{array}{l}\mathrm{N} \\
\text { (thousands) }\end{array}$ & $\%$ & $\mathrm{~N}$ & $\%$ & $\begin{array}{c}\text { Low } \\
95 \% \\
\text { CI }\end{array}$ & $\begin{array}{c}\text { High } \\
95 \% \\
\text { CI }\end{array}$ & $\mathrm{N}$ & $\%$ & $\begin{array}{c}\text { Low } \\
95 \% \\
\text { CI }\end{array}$ & $\begin{array}{c}\text { High } \\
95 \% \\
\text { CI }\end{array}$ \\
\hline \multicolumn{11}{|l|}{ Academic rank } \\
\hline Deans & 4.8 & 2 & 81 & 5 & 4.1 & 6.3 & & & & \\
\hline Heads of department & 22.3 & 8 & 120 & 8 & 6.4 & 9.0 & & & & \\
\hline Professors & 38.1 & 14 & 152 & 10 & 8.3 & 11.2 & 111 & 16 & 13.0 & 18.4 \\
\hline Associate professors & 134.5 & 48 & 707 & 45 & 42.9 & 47.8 & 463 & 65 & 62.0 & 69.0 \\
\hline Senior lecturer & 50.3 & 18 & 254 & 16 & 14.5 & 18.1 & & & & \\
\hline $\begin{array}{l}\text { Teachers and teaching } \\
\text { assistants }\end{array}$ & 29.8 & 11 & 244 & 16 & 13.9 & 17.5 & 133 & 19 & 15.9 & 21.7 \\
\hline \multicolumn{11}{|l|}{ Gender } \\
\hline Female & 159.5 & 57 & 924 & 59 & 57 & 62 & 381 & 54 & 50 & 57 \\
\hline Male & 120.3 & 43 & 635 & 41 & 38 & 43 & 327 & 46 & 43 & 50 \\
\hline \multicolumn{11}{|l|}{ Degree } \\
\hline No degree & 77.4 & 28 & 528 & 34 & 32 & 36 & & & & \\
\hline Candidate / PhD degree & 160 & 57 & 864 & 55 & 53 & 58 & & & & \\
\hline Doctor degree & 42.4 & 15 & 167 & 11 & 9 & 12 & 120 & 17 & 14 & 20 \\
\hline \multicolumn{11}{|l|}{ Age } \\
\hline under 25 & & 1.1 & & 1.3 & 0.7 & 1.9 & & 0.0 & 0.0 & 0.0 \\
\hline $25-29$ & & 6.5 & & 7.1 & 5.8 & 8.4 & & 3.1 & 1.8 & 4.4 \\
\hline $30-34$ & & 10.8 & & 13.1 & 11.4 & 14.8 & & 10.7 & 8.4 & 13.0 \\
\hline $35-39$ & & 13.1 & & 15.2 & 13.4 & 17.0 & & 16.1 & 13.4 & 18.8 \\
\hline $40-45$ & & 11.4 & & 18.1 & 16.2 & 20.0 & & 18.5 & 15.6 & 21.4 \\
\hline $46-49$ & & 8.9 & & 9.3 & 7.9 & 10.7 & & 9.5 & 7.3 & 11.7 \\
\hline $50-54$ & & 9.8 & & 11.5 & 9.9 & 13.1 & & 12.4 & 10.0 & 14.8 \\
\hline $55-59$ & & 10.5 & & 10.1 & 8.6 & 11.6 & & 9.5 & 7.3 & 11.7 \\
\hline $60-64$ & & 10.0 & & 6.5 & 5.3 & 7.7 & & 8.2 & 6.2 & 10.2 \\
\hline $65+$ & & 18.0 & & 7.9 & 6.6 & 9.2 & & 12.0 & 9.6 & 14.4 \\
\hline Total & 279.8 & 100 & 1559 & & 100 & & 707 & & 100 & \\
\hline
\end{tabular}

Since the focus of the research is on publication activity, respondents from cultural, theatre, and dance higher education institutions and respondents who teach physical culture and civil defense were excluded from the analysis. Faculty from private universities were also excluded from the sample for several reasons. Although the private higher education sector in Russia is sizeable, comprising about $40 \%$ of the total number of higher education institutions, private institutions are notorious for the low quality of education they provide. Average Unified State Exam scores of students enrolled at such institutions are much lower than those of their counterparts at public universities; the faculty body is rather weak, as most of them work part-time on hourly based contracts; and, finally, the infrastructure of private 
institutions is rather poor (Yudkevich, 2014). Moreover, there are no private PhD-granting universities and institutions in Russia, and this was crucial for our research design those respondents who did not have $\mathrm{PhD}$ degrees (the Russian equivalent of a $\mathrm{PhD}$ is Candidate of Sciences degree) were excluded from the analysis. Also, in our final sample for the analysis we did not include non-permanent workers and those academics who had less than three years of experience in academia in order to obtain the correct classification of faculty in terms of academic inbreeding. Thus, the final sample size used in our research was 708 respondents. As a result of the various conditions detailed above, our sample was still not completely representative by age, academic rank and degree, although the biases were small and practically the same as in the overall sample.

\section{Dependent variables}

Faculty productivity in publishing was the dependent variable distinguished on the basis of the self-report. Three variables for publications were used in analysis: 1) the number of articles in Russian journals; 2) the number of articles in journals published by the university where the faculty work; 3) the number of articles in foreign journals. Participants were asked to report the number of articles published during the year prior to the survey. Mean values for each of dependent variables are shown in Table 2. 
Table 2. Descriptive statistics.

\begin{tabular}{llll}
\hline Variable & Obs. & Mean & SD \\
\hline Dependent variables & & & \\
Articles in Russian journals & 661 & 2.34 & 4.57 \\
Articles in journals published by own university & 665 & 1.20 & 1.84 \\
Articles in foreign journals & 697 & 0.25 & 0.69 \\
Control variables & & & \\
Gender (1 = male) & 708 & 0.46 & 0.50 \\
Age & 708 & 47.87 & 12.24 \\
Professor & 707 & 0.16 & 0.36 \\
Associate professor & 707 & 0.65 & 0.48 \\
Teaches graduate students & 707 & 0.16 & 0.37 \\
Participation in research projects & 706 & 0.47 & 0.50 \\
Had funding to perform research & 706 & 0.22 & 0.42 \\
Special university status & 708 & 0.13 & 0.33 \\
Mean USE & 665 & 67.88 & 9.48 \\
Bonus for papers in WoS/Scopus & 696 & 0.32 & 0.47 \\
Bonus for papers in Russian journals & 696 & 0.32 & 0.47 \\
Log(N of papers in Scopus + 1) & 665 & 15.70 & 24.95 \\
Humanities & 708 & 0.18 & 0.38 \\
Mathematics and computer sciences & 708 & 0.10 & 0.30 \\
Natural sciences & 708 & 0.11 & 0.32 \\
Social sciences & 708 & 0.32 & 0.47 \\
Technology & 708 & 0.21 & 0.41 \\
\hline
\end{tabular}

\section{Independent variables}

Following Berelson (1960), information on studying and developing career at the early stage was used for classification of the faculty into groups in terms of inbreeding. Three main groups of faculty are distinguished based on different combination of these information: 1) inbreds (who studied at the university where they now work), 2) silver-corded (who studied at the university where they now work, but started their academic career in different university), 3) non-inbreds (who did not study at the university where they now work). Following Horta's (2013) methodology, inbreds group were also divided into pure-inbreds (who work at the same university throughout their career) and mobile inbreds (who changed the place of work at least once); non-inbreds group were divided into adherents (who work at the same university throughout their career, but did not study at this university) and mobile non-inbreds (who did not study at the university they work at and changed place of work at 
least once). Table 3 reports the number of faculty in each group.

Table 3. The number of faculty in different groups.

\begin{tabular}{ll}
\hline Group & Size \\
\hline Inbreds & 318 \\
Silver-corded & 116 \\
Non-inbreds & 267 \\
\hline Pure-inbreds & 289 \\
Mobile inbreds & 29 \\
Silver-corded & 116 \\
Adherents & 130 \\
Mobile non-inbreds & 137 \\
\hline
\end{tabular}

\section{Control variables}

The analysis also involved control variables that are potentially connected with the number of publications that faculty have. The first group of control variables included individual characteristics of academics: gender, age, academic rank (two dummy-variables for full professor and associate professor positions), three dummy-variables for teaching graduate students, participating in research projects, and having research project funding. The second group of control variables included the characteristics of the institution where the respondent worked at the time of completing the survey. It is supposed that academics with different research productivity and different publishing strategies work in higher educational institutions of different quality. Five institutional characteristics were used: special university status ('National Research University' which reflects the effectiveness of the educational process and its integration with scientific research), the mean Unified State Exam (USE) scores of students matriculated to tuition-free places, the logarithm of the number of papers per 100 academics indexed in the Scopus published over the past 5 years (plus 1), two dummy-variables for bonuses which are paid for papers published in Russian journals and journals indexed in Web of Science or Scopus. The data on mean USE scores and the number 
of papers was determined on the basis of the monitoring of higher educational institutions (2016, http://indicators.miccedu.ru/monitoring/) conducted by the Ministry of Education and Science. Scientific field was also controlled by five dummy-variables for social sciences (e.g. sociology, psychology, business and administration, economics, teacher training and education science), natural sciences (e.g. physics, chemistry, biology, and geography), humanities (e.g. philosophy, philology, history, arts, and law), mathematics and computer sciences, and technology (e.g. engineering, architecture, manufacturing and construction). The category 'other' was a reference. The descriptive statistics of control variables are presented in Table 2 .

\section{Data analysis}

The dependent variables are count variables with many zeros (there are a lot of faculty in the sample who have no publications at all). This kind of data requires special regression models for analysis: zero-inflated negative binomial (ZINB) or negative binomial logit hurdle (NBLH) (Loeys, Moerkerke, De Smet, \& Buysse, 2012; Zeileis, Kleiber, \& Jackman, 2008). These models are mixture models in which the complete distribution of the dependent variable is split into two separate components. In the ZINB models, the zero part represents the probability of excess zeros and the count part represents the non-excess zeros and nonzero counts. In the NBLH models, the zero and non-zero counts are clearly separated, the two parts of the models representing zero versus non-zero values and non-zero counts. In terms of the variables used, the zero part assesses the effect of belonging to one of groups on having at least one publication, and the count part assesses the effect of belonging to inbreds on the number of publications. The NBLH models were used for analysis because they are easier to interpret. The NBLH regression models were calculated to examine the relationship between academic inbreeding and publication productivity. For a simpler interpretation, regression 
coefficients may be exponentiated and transformed into odds ratios (OR) in zero parts and rate ratios $(R R)$ in the count parts. In percentages $\left(100 *\left(e^{B}-1\right)\right)$ OR reflects the percentage decrease $(\mathrm{OR}<1)$ or increase $(\mathrm{OR}>1)$ in the odds of having at least one publication, whereas $R R$ reflects the percentage decrease $(R R<1)$ or increase $(R R>1)$ in the expected number of publications for each unit increase in the independent variable, controlling for other predictors. All calculations were performed in R (R Core Team, 2016). To fit these models the hurdle function from the pscl package (Zeileis et al., 2008) was used.

\section{Limitations}

The analytical strategy is not without limitations. First, we analyzed the self-reported data on publishing productivity. Despite their relative reliability (Chan, 2009), there is no way to evaluate the quality of articles. It does not necessarily follow that the absence of significant differences in the number of articles between inbreds and non-inbreds means there is no difference in their quality. Inbred and non-inbred faculty may have an equal number of articles of different quality. With our data it is not possible to test this hypothesis. Future studies comparing inbreds and non-inbreds need to measure not only the number but also the quality of publications. Second, we analyzed only one type of publications - articles. This type is not equally important in different research fields. Large-scale analysis of the place of serials in referencing practices in different disciplines showed that journal articles are increasingly important in the natural sciences and in a number of social sciences, but account for less than $50 \%$ of the citations in some other social sciences disciplines and in the humanities (Larivière, Archambault, Gingras, \& Vignola-Gagné, 2006). In computer sciences and in the humanities, other types of publication are more valuable (proceeding papers and books, respectively). However, there is not enough variation in these types of publication in our dataset. To take the research field into consideration our regressions included a number of 
dummy-variables for research fields.

\section{Results}

Table 4 shows the regression coefficients from NBLH models for articles in Russian journals, in journals published by the university where faculty work, and in foreign journals. Results show that publishing productivity is conditioned by both individual characteristics of faculty and by the characteristics of the university where they work. Young age, having high academic rank, participation in research projects, having research funding, and having the opportunity to receive a bonus for papers in Russian journals all determine the production of articles in Russian journals. The same predictors, with the exception of the bonus, determine the production of articles in journals published by the university where the faculty work. The production of articles in foreign journals, however, has a slightly different set of predictors, such as young age, teaching graduate students, participating in research projects, and having the opportunity to receive a bonus for papers in journals indexed in WoS/Scopus.

Interestingly, we found no gender differences in publishing productivity, although the previous studies found that men produce more papers than women in almost all disciplines in Russia (Paul-Hus et al., 2015). However, it is important to note that the sample analyzed was biased toward more adult faculty because of our focus on inbreeding. Another recently published piece of research on Russian scholars, based on the data from the international project on 'Careers of Doctorate Holders', did not find any gender difference in the number of different types of publications among researchers in the older age cohort (41 years or more) (Fursov, Roshina, \& Balmush, 2016). Perhaps the gender differences in publishing productivity may differ in age cohorts. However, this question needs a separate study. We also found a negative correlation between age and the probability of having at least one article of all the types. Although this correlation may not be robust, it is not unexpected and 
may be explained by the natural decrease of productivity and by the characteristics of the older generation of faculty, who had low incentives for publishing and were more teachingoriented (Yudkevich, 2014).

High academic rank and receiving funding to perform research increase the probability of having publications in Russian journals, but not in foreign journals. This is not a surprising result, as both variables correlate with having more resources for research - and, and as a result, articles. However, not every research project ends with articles in foreign journals. Publishing only in Russian journals is a widespread practice among Russian faculty, as often it is substantially easier and faster. It is especially important in conditions in which a large proportion of Russian research grants are individual, small, and of short duration (one or two years). Participation in collective research projects and the existence of a publication bonus system in universities increase the probability of having articles in both Russian and in foreign journals. These correlations are expected, reasonable, and in line with previous research (Fursov et al., 2016; Horta, 2013).

Completely the same patterns in control variables are observed in Table 5. In total, these results from the NBLH models look reasonable and explainable; thus, we can look at the results of testing differences in publishing productivity between groups of faculty depending on their inbreeding status.

The NBLH models comparing pure-inbreds, mobile inbreds, silver-corded, and adherents with mobile non-inbreds (Table 4) demonstrate no significant differences in the probability of having at least one article and in the number of articles both in Russian journals and in journals published by their own university between mobile non-inbred faculty (the least inbred group) and the other groups. Differences were found only in the probability of having at least one article and in the number of articles in foreign journals. Pure-inbreds (the most extreme group in terms of inbreeding) have a lower number of articles ( $R R=0.44$, 
$[95 \% \mathrm{CI}=0.22-0.90], p=.0235)$ and a lower probability of having at least one article in a foreign journal $(\mathrm{OR}=0.51,[95 \% \mathrm{CI}=0.27-0.97], p=.0395)$ compared to mobile noninbreds. However, in both cases the $p$-values are very close to the conventional cutoff (.05) and $95 \%$ confidence intervals are extremely wide; therefore, these differences are very unlikely to be robust. Figure 1 also demonstrates the lack of substantial differences between all five groups of faculty in terms of probability of having and distribution of the number of articles.

Table 5 shows the regression coefficients from NBLH models for the same types of articles comparing inbreds (pure-inbreds and mobile inbreds) and silver-corded faculty with non-inbreds (adherents and mobile non-inbreds). There are no significant differences in all types of articles between these groups of faculty. Figure 2 also demonstrates the lack of substantial differences between these three groups of faculty in terms of the probability of having a number of articles, and the distribution of, those articles. Therefore, we may conclude that there are no substantial and robust differences in publication activity between inbreds, silver-corded faculty and non-inbreds. 
Table 4. Summary of the NBLH models comparing pure-inbreds, mobile inbreds, silvercorded, and adherents with mobile non-inbreds.

\begin{tabular}{|c|c|c|c|c|c|c|}
\hline \multirow[t]{2}{*}{ Predictors } & \multicolumn{2}{|c|}{$\begin{array}{c}\text { Articles in Russian } \\
\text { journals }\end{array}$} & \multicolumn{2}{|c|}{$\begin{array}{c}\text { Articles in } \\
\text { university journals }\end{array}$} & \multicolumn{2}{|c|}{$\begin{array}{c}\text { Articles in foreign } \\
\text { journals }\end{array}$} \\
\hline & $\begin{array}{l}\text { Count } \\
\text { part }\end{array}$ & $\begin{array}{l}\text { Zero } \\
\text { part }\end{array}$ & $\begin{array}{l}\text { Count } \\
\text { part }\end{array}$ & $\begin{array}{l}\text { Zero } \\
\text { part }\end{array}$ & $\begin{array}{l}\text { Count } \\
\text { part }\end{array}$ & $\begin{array}{l}\text { Zero } \\
\text { part }\end{array}$ \\
\hline Pure-inbreds & $\begin{array}{l}0.060 \\
(0.264)\end{array}$ & $\begin{array}{l}-0.052 \\
(0.265)\end{array}$ & $\begin{array}{l}0.248 \\
(0.236)\end{array}$ & $\begin{array}{l}0.116 \\
(0.243)\end{array}$ & $\begin{array}{l}-0.814^{*} \\
(0.360)\end{array}$ & $\begin{array}{l}-0.667 * \\
(0.324)\end{array}$ \\
\hline Mobile inbreds & $\begin{array}{l}0.223 \\
(0.502)\end{array}$ & $\begin{array}{l}0.134 \\
(0.506)\end{array}$ & $\begin{array}{l}0.666 \\
(0.377)\end{array}$ & $\begin{array}{l}0.102 \\
(0.448)\end{array}$ & $\begin{array}{l}-0.113 \\
(0.503)\end{array}$ & $\begin{array}{l}-0.200 \\
(0.566)\end{array}$ \\
\hline Silver-corded & $\begin{array}{l}-0.250 \\
(0.311)\end{array}$ & $\begin{array}{l}0.255 \\
(0.313)\end{array}$ & $\begin{array}{l}0.268 \\
(0.280)\end{array}$ & $\begin{array}{l}-0.234 \\
(0.287)\end{array}$ & $\begin{array}{l}-0.722 \\
(0.419)\end{array}$ & $\begin{array}{l}-0.405 \\
(0.384)\end{array}$ \\
\hline Adherents & $\begin{array}{l}0.235 \\
(0.305)\end{array}$ & $\begin{array}{l}0.378 \\
(0.310)\end{array}$ & $\begin{array}{l}0.337 \\
(0.292)\end{array}$ & $\begin{array}{l}-0.294 \\
(0.282)\end{array}$ & $\begin{array}{l}-0.478 \\
(0.398)\end{array}$ & $\begin{array}{l}-0.309 \\
(0.379)\end{array}$ \\
\hline Gender $(1=$ male $)$ & $\begin{array}{l}0.053 \\
(0.214)\end{array}$ & $\begin{array}{l}-0.199 \\
(0.200)\end{array}$ & $\begin{array}{l}0.081 \\
(0.180)\end{array}$ & $\begin{array}{l}-0.154 \\
(0.185)\end{array}$ & $\begin{array}{l}-0.227 \\
(0.326)\end{array}$ & $\begin{array}{l}-0.082 \\
(0.254)\end{array}$ \\
\hline Age & $\begin{array}{l}-0.006 \\
(0.010)\end{array}$ & $\begin{array}{l}-0.020^{*} \\
(0.009)\end{array}$ & $\begin{array}{l}-0.009 \\
(0.008)\end{array}$ & $\begin{array}{l}-0.020^{*} \\
(0.008)\end{array}$ & $\begin{array}{l}0.013 \\
(0.012)\end{array}$ & $\begin{array}{l}-0.025^{*} \\
(0.012)\end{array}$ \\
\hline Professor & $\begin{array}{l}0.197 \\
(0.340)\end{array}$ & $\begin{array}{l}1.425 * * * \\
(0.386)\end{array}$ & $\begin{array}{l}0.504 \\
(0.331)\end{array}$ & $\begin{array}{l}0.788 * \\
(0.342)\end{array}$ & $\begin{array}{l}-0.457 \\
(0.475)\end{array}$ & $\begin{array}{l}0.839 \\
(0.451)\end{array}$ \\
\hline Associate professor & $\begin{array}{l}-0.388 \\
(0.275)\end{array}$ & $\begin{array}{l}0.346 \\
(0.236)\end{array}$ & $\begin{array}{l}0.178 \\
(0.230)\end{array}$ & $\begin{array}{l}0.182 \\
(0.224)\end{array}$ & $\begin{array}{l}-0.059 \\
(0.394)\end{array}$ & $\begin{array}{l}0.008 \\
(0.322)\end{array}$ \\
\hline Teaches graduate students & $\begin{array}{l}0.041 \\
(0.279)\end{array}$ & $\begin{array}{l}0.267 \\
(0.293)\end{array}$ & $\begin{array}{l}-0.227 \\
(0.251)\end{array}$ & $\begin{array}{l}0.037 \\
(0.262)\end{array}$ & $\begin{array}{l}0.778 * \\
(0.339)\end{array}$ & $\begin{array}{l}0.244 \\
(0.339)\end{array}$ \\
\hline Participation in research projects & $\begin{array}{l}-0.004 \\
(0.196)\end{array}$ & $\begin{array}{l}0.569 * * \\
(0.192)\end{array}$ & $\begin{array}{l}-0.028 \\
(0.172)\end{array}$ & $\begin{array}{l}0.614 * * * \\
(0.178)\end{array}$ & $\begin{array}{l}-0.312 \\
(0.285)\end{array}$ & $\begin{array}{l}0.719 * * \\
(0.248)\end{array}$ \\
\hline Had funding to perform research & $\begin{array}{l}-0.087 \\
(0.211)\end{array}$ & $\begin{array}{l}1.101^{* * * *} \\
(0.259)\end{array}$ & $\begin{array}{l}0.213 \\
(0.183)\end{array}$ & $\begin{array}{l}0.438 * \\
(0.214)\end{array}$ & $\begin{array}{l}-0.119 \\
(0.316)\end{array}$ & $\begin{array}{l}0.329 \\
(0.269)\end{array}$ \\
\hline Special university status & $\begin{array}{l}0.423 \\
(0.335)\end{array}$ & $\begin{array}{l}-0.576 \\
(0.335)\end{array}$ & $\begin{array}{l}-0.394 \\
(0.314)\end{array}$ & $\begin{array}{l}-0.597 \\
(0.308)\end{array}$ & $\begin{array}{l}0.063 \\
(0.470)\end{array}$ & $\begin{array}{l}-0.260 \\
(0.410)\end{array}$ \\
\hline Mean USE & $\begin{array}{l}0.017 \\
(0.012)\end{array}$ & $\begin{array}{l}0.005 \\
(0.011)\end{array}$ & $\begin{array}{l}0.008 \\
(0.011)\end{array}$ & $\begin{array}{l}-0.013 \\
(0.010)\end{array}$ & $\begin{array}{l}0.006 \\
(0.023)\end{array}$ & $\begin{array}{l}-0.017 \\
(0.015)\end{array}$ \\
\hline Bonus for papers in WoS/Scopus & - & - & - & - & $\begin{array}{l}-0.015 \\
(0.303)\end{array}$ & $\begin{array}{l}0.802 * * \\
(0.247)\end{array}$ \\
\hline $\begin{array}{l}\text { Bonus for papers in Russian } \\
\text { journals }\end{array}$ & $\begin{array}{l}-0.084 \\
(0.208)\end{array}$ & $\begin{array}{l}0.542 * \\
(0.212)\end{array}$ & $\begin{array}{l}0.142 \\
(0.170)\end{array}$ & $\begin{array}{l}0.052 \\
(0.191)\end{array}$ & - & - \\
\hline $\log (\mathrm{N}$ of papers in Scopus +1$)$ & $\begin{array}{l}-0.400 * * \\
(0.127)\end{array}$ & $\begin{array}{l}0.297 * \\
(0.121)\end{array}$ & $\begin{array}{l}0.123 \\
(0.108)\end{array}$ & $\begin{array}{l}0.130 \\
(0.111)\end{array}$ & $\begin{array}{l}0.157 \\
(0.187)\end{array}$ & $\begin{array}{l}0.376^{*} \\
(0.156)\end{array}$ \\
\hline Humanities & $\begin{array}{l}0.647 \\
(0.391)\end{array}$ & $\begin{array}{l}-0.603 \\
(0.387)\end{array}$ & $\begin{array}{l}0.482 \\
(0.362)\end{array}$ & $\begin{array}{l}-0.270 \\
(0.368)\end{array}$ & $\begin{array}{l}0.539 \\
(1.056)\end{array}$ & $\begin{array}{l}0.559 \\
(0.614)\end{array}$ \\
\hline $\begin{array}{l}\text { Mathematics and computer } \\
\text { sciences }\end{array}$ & $\begin{array}{l}0.853 \\
(0.487)\end{array}$ & $\begin{array}{l}-0.691 \\
(0.444)\end{array}$ & $\begin{array}{l}0.105 \\
(0.425)\end{array}$ & $\begin{array}{l}-0.156 \\
(0.419)\end{array}$ & $\begin{array}{l}0.618 \\
(1.097)\end{array}$ & $\begin{array}{l}0.918 \\
(0.646)\end{array}$ \\
\hline Natural sciences & $\begin{array}{l}0.184 \\
(0.422)\end{array}$ & $\begin{array}{l}-0.559 \\
(0.413)\end{array}$ & $\begin{array}{l}0.240 \\
(0.385)\end{array}$ & $\begin{array}{l}-0.057 \\
(0.392)\end{array}$ & $\begin{array}{l}0.989 \\
(1.063)\end{array}$ & $\begin{array}{l}0.643 \\
(0.631)\end{array}$ \\
\hline Social sciences & $\begin{array}{l}0.429 \\
(0.368)\end{array}$ & $\begin{array}{l}0.139 \\
(0.386)\end{array}$ & $\begin{array}{l}0.071 \\
(0.346)\end{array}$ & $\begin{array}{l}-0.007 \\
(0.357)\end{array}$ & $\begin{array}{l}0.378 \\
(1.076)\end{array}$ & $\begin{array}{l}0.595 \\
(0.591)\end{array}$ \\
\hline Technology & $\begin{array}{l}0.767 * \\
(0.385)\end{array}$ & $\begin{array}{l}-0.171 \\
(0.397)\end{array}$ & $\begin{array}{l}0.164 \\
(0.353)\end{array}$ & $\begin{array}{l}0.191 \\
(0.371)\end{array}$ & $\begin{array}{l}0.877 \\
(1.089)\end{array}$ & $\begin{array}{l}0.290 \\
(0.614)\end{array}$ \\
\hline $\begin{array}{l}\text { Log-likelihood } \\
\text { AIC } \\
\mathrm{N}\end{array}$ & $\begin{array}{r}-1 \\
23 \\
0\end{array}$ & $\begin{array}{l}8.5 \\
3.1 \\
1\end{array}$ & & $\begin{array}{l}2.0 \\
0.0 \\
2\end{array}$ & & \\
\hline
\end{tabular}

Notes: $*-p<.05, * *-p<.01, * * *-p<.001$, Mobile non-inbreds are reference category. 

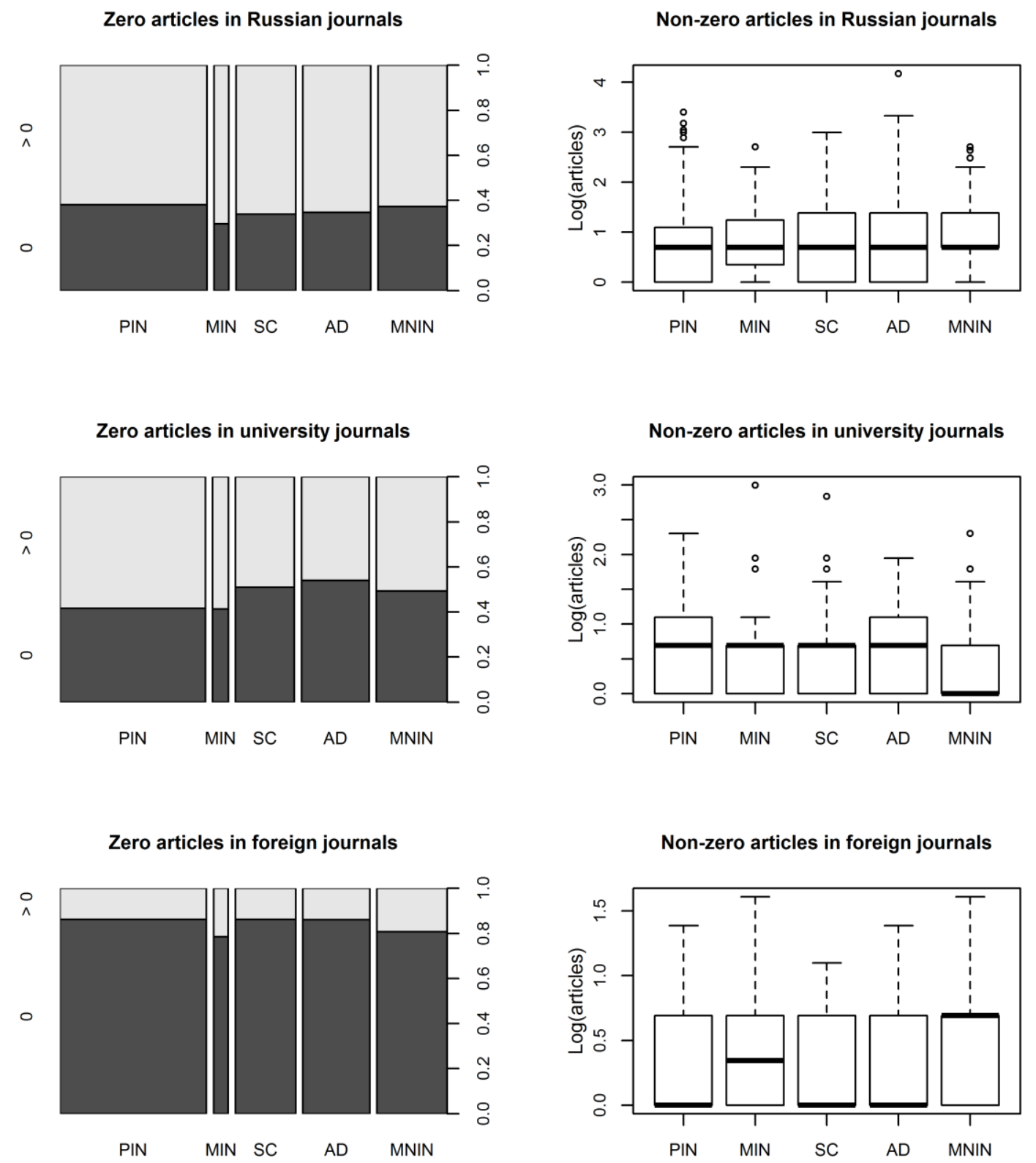

Figure 1. Probability of publishing and distribution of the number of different types of articles for pure-inbreds (PIN), mobile inbreds (MIN), silver-corded (SC), adherents (AD), and mobile non-inbreds (MNIN). 
Table 5. Summary of the NBLH models comparing inbreds and silver-corded with noninbreds.

\begin{tabular}{|c|c|c|c|c|c|c|}
\hline \multirow[t]{2}{*}{ Predictors } & \multicolumn{2}{|c|}{$\begin{array}{c}\text { Articles in Russian } \\
\text { journals }\end{array}$} & \multicolumn{2}{|c|}{$\begin{array}{c}\text { Articles in } \\
\text { university journals }\end{array}$} & \multicolumn{2}{|c|}{$\begin{array}{c}\text { Articles in foreign } \\
\text { journals }\end{array}$} \\
\hline & $\begin{array}{c}\text { Count } \\
\text { part }\end{array}$ & $\begin{array}{c}\text { Zero } \\
\text { part }\end{array}$ & $\begin{array}{c}\text { Count } \\
\text { part }\end{array}$ & $\begin{array}{c}\text { Zero } \\
\text { part }\end{array}$ & $\begin{array}{c}\text { Count } \\
\text { part }\end{array}$ & $\begin{array}{c}\text { Zero } \\
\text { part }\end{array}$ \\
\hline Inbreds & $\begin{array}{l}-0.039 \\
(0.215)\end{array}$ & $\begin{array}{l}-0.226 \\
(0.210)\end{array}$ & $\begin{array}{l}0.154 \\
(0.187)\end{array}$ & $\begin{array}{l}0.259 \\
(0.192)\end{array}$ & $\begin{array}{l}-0.481 \\
(0.308)\end{array}$ & $\begin{array}{l}-0.469 \\
(0.269)\end{array}$ \\
\hline Silver-corded & $\begin{array}{l}-0.368 \\
(0.272)\end{array}$ & $\begin{array}{l}0.064 \\
(0.272)\end{array}$ & $\begin{array}{l}0.108 \\
(0.249)\end{array}$ & $\begin{array}{l}-0.089 \\
(0.251)\end{array}$ & $\begin{array}{l}-0.524 \\
(0.400)\end{array}$ & $\begin{array}{l}-0.258 \\
(0.346)\end{array}$ \\
\hline Gender $(1=$ male $)$ & $\begin{array}{l}0.056 \\
(0.213)\end{array}$ & $\begin{array}{l}-0.182 \\
(0.199)\end{array}$ & $\begin{array}{l}0.098 \\
(0.182)\end{array}$ & $\begin{array}{l}-0.162 \\
(0.184)\end{array}$ & $\begin{array}{l}-0.118 \\
(0.320)\end{array}$ & $\begin{array}{l}-0.076 \\
(0.251)\end{array}$ \\
\hline Age & $\begin{array}{l}-0.005 \\
(0.010)\end{array}$ & $\begin{array}{l}-0.019 * \\
(0.009)\end{array}$ & $\begin{array}{l}-0.010 \\
(0.008)\end{array}$ & $\begin{array}{l}-0.020^{*} \\
(0.008)\end{array}$ & $\begin{array}{l}0.013 \\
(0.012)\end{array}$ & $\begin{array}{l}-0.025^{*} \\
(0.012)\end{array}$ \\
\hline Professor & $\begin{array}{l}0.200 \\
(0.340)\end{array}$ & $\begin{array}{l}1.389 * * * \\
(0.381)\end{array}$ & $\begin{array}{l}0.567 \\
(0.330)\end{array}$ & $\begin{array}{l}0.827 * \\
(0.338)\end{array}$ & $\begin{array}{l}-0.325 \\
(0.465)\end{array}$ & $\begin{array}{l}0.905^{*} \\
(0.447)\end{array}$ \\
\hline Associate professor & $\begin{array}{l}-0.376 \\
(0.275)\end{array}$ & $\begin{array}{l}0.341 \\
(0.235)\end{array}$ & $\begin{array}{l}0.224 \\
(0.232)\end{array}$ & $\begin{array}{l}0.186 \\
(0.224)\end{array}$ & $\begin{array}{l}-0.096 \\
(0.389)\end{array}$ & $\begin{array}{l}0.026 \\
(0.322)\end{array}$ \\
\hline Teaches graduate students & $\begin{array}{l}0.035 \\
(0.279)\end{array}$ & $\begin{array}{l}0.302 \\
(0.290)\end{array}$ & $\begin{array}{l}-0.229 \\
(0.252)\end{array}$ & $\begin{array}{l}0.005 \\
(0.259)\end{array}$ & $\begin{array}{l}0.659^{*} \\
(0.323)\end{array}$ & $\begin{array}{l}0.197 \\
(0.336)\end{array}$ \\
\hline Participation in research projects & $\begin{array}{l}0.029 \\
(0.191)\end{array}$ & $\begin{array}{l}0.583 * * \\
(0.191)\end{array}$ & $\begin{array}{l}0.010 \\
(0.174)\end{array}$ & $\begin{array}{l}0.603 * * * \\
(0.177)\end{array}$ & $\begin{array}{l}-0.335 \\
(0.286)\end{array}$ & $\begin{array}{l}0.716 * * \\
(0.247)\end{array}$ \\
\hline Had funding to perform research & $\begin{array}{l}-0.094 \\
(0.211)\end{array}$ & $\begin{array}{l}1.076 * * * \\
(0.258)\end{array}$ & $\begin{array}{l}0.176 \\
(0.185)\end{array}$ & $\begin{array}{l}0.450^{*} \\
(0.213)\end{array}$ & $\begin{array}{l}-0.043 \\
(0.289)\end{array}$ & $\begin{array}{l}0.326 \\
(0.268)\end{array}$ \\
\hline Special university status & $\begin{array}{l}0.458 \\
(0.332)\end{array}$ & $\begin{array}{l}-0.547 \\
(0.333)\end{array}$ & $\begin{array}{l}-0.355 \\
(0.310)\end{array}$ & $\begin{array}{l}-0.618^{*} \\
(0.306)\end{array}$ & $\begin{array}{l}-0.068 \\
(0.448)\end{array}$ & $\begin{array}{l}-0.296 \\
(0.408)\end{array}$ \\
\hline Mean USE & $\begin{array}{l}0.017 \\
(0.012)\end{array}$ & $\begin{array}{l}0.003 \\
(0.011)\end{array}$ & $\begin{array}{l}0.007 \\
(0.011)\end{array}$ & $\begin{array}{l}-0.012 \\
(0.010)\end{array}$ & $\begin{array}{l}0.010 \\
(0.024)\end{array}$ & $\begin{array}{l}-0.015 \\
(0.015)\end{array}$ \\
\hline Bonus for papers in WoS/Scopus & - & - & - & - & $\begin{array}{l}-0.003 \\
(0.302)\end{array}$ & $\begin{array}{l}0.818 * * * \\
(0.246)\end{array}$ \\
\hline $\begin{array}{l}\text { Bonus for papers in Russian } \\
\text { journals }\end{array}$ & $\begin{array}{l}-0.117 \\
(0.204)\end{array}$ & $\begin{array}{l}0.524^{*} \\
(0.211)\end{array}$ & $\begin{array}{l}0.132 \\
(0.172)\end{array}$ & $\begin{array}{l}0.066 \\
(0.190)\end{array}$ & - & - \\
\hline $\log (\mathrm{N}$ of papers in Scopus +1$)$ & $\begin{array}{l}-0.415^{* * *} \\
(0.124)\end{array}$ & $\begin{array}{l}0.294 * \\
(0.121)\end{array}$ & $\begin{array}{l}0.107 \\
(0.106)\end{array}$ & $\begin{array}{l}0.137 \\
(0.110)\end{array}$ & $\begin{array}{l}0.189 \\
(0.189)\end{array}$ & $\begin{array}{l}0.386^{*} \\
(0.155)\end{array}$ \\
\hline Humanities & $\begin{array}{l}0.644 \\
(0.393)\end{array}$ & $\begin{array}{l}-0.618 \\
(0.386)\end{array}$ & $\begin{array}{l}0.499 \\
(0.364)\end{array}$ & $\begin{array}{l}-0.252 \\
(0.367)\end{array}$ & $\begin{array}{l}0.780 \\
(1.039)\end{array}$ & $\begin{array}{l}0.582 \\
(0.614)\end{array}$ \\
\hline $\begin{array}{l}\text { Mathematics and computer } \\
\text { sciences }\end{array}$ & $\begin{array}{l}0.841 \\
(0.485)\end{array}$ & $\begin{array}{l}-0.718 \\
(0.443)\end{array}$ & $\begin{array}{l}0.041 \\
(0.428)\end{array}$ & $\begin{array}{l}-0.138 \\
(0.418)\end{array}$ & $\begin{array}{l}0.836 \\
(1.074)\end{array}$ & $\begin{array}{l}0.915 \\
(0.645)\end{array}$ \\
\hline Natural sciences & $\begin{array}{l}0.154 \\
(0.419)\end{array}$ & $\begin{array}{l}-0.569 \\
(0.411)\end{array}$ & $\begin{array}{l}0.162 \\
(0.383)\end{array}$ & $\begin{array}{l}-0.049 \\
(0.391)\end{array}$ & $\begin{array}{l}1.091 \\
(1.056)\end{array}$ & $\begin{array}{l}0.653 \\
(0.630)\end{array}$ \\
\hline Social sciences & $\begin{array}{l}0.410 \\
(0.369)\end{array}$ & $\begin{array}{l}0.113 \\
(0.384)\end{array}$ & $\begin{array}{l}0.019 \\
(0.346)\end{array}$ & $\begin{array}{l}0.010 \\
(0.356)\end{array}$ & $\begin{array}{l}0.659 \\
(1.060)\end{array}$ & $\begin{array}{l}0.628 \\
(0.591)\end{array}$ \\
\hline Technology & $\begin{array}{l}0.726 \\
(0.380) \\
\end{array}$ & $\begin{array}{l}-0.193 \\
(0.394) \\
\end{array}$ & $\begin{array}{l}0.114 \\
(0.355) \\
\end{array}$ & $\begin{array}{l}0.206 \\
(0.371) \\
\end{array}$ & $\begin{array}{l}1.058 \\
(1.071) \\
\end{array}$ & $\begin{array}{l}0.300 \\
(0.614) \\
\end{array}$ \\
\hline Log-likelihood & & & & & & \\
\hline AIC & & & & & & \\
\hline $\mathrm{N}$ & & & & & & \\
\hline
\end{tabular}




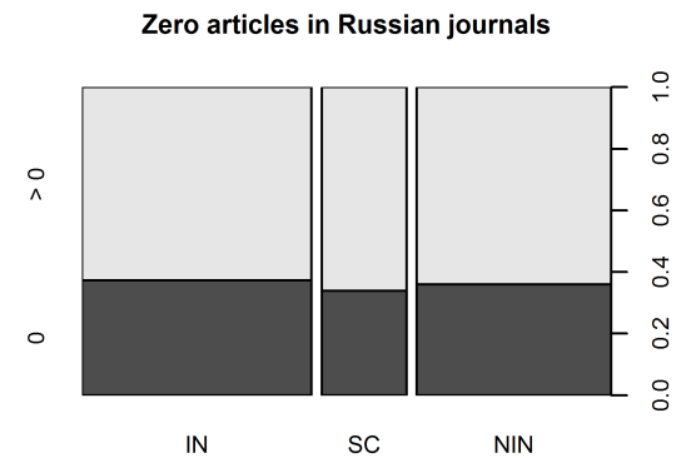

Zero articles in university journals

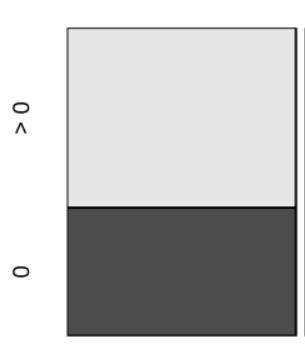

IN

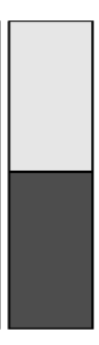

SC

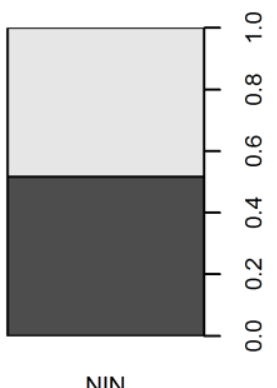

NIN

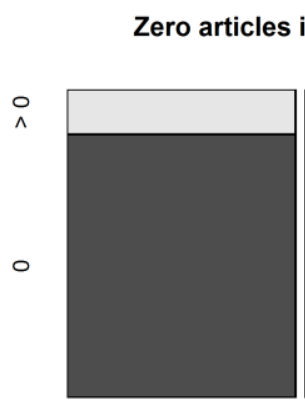

IN

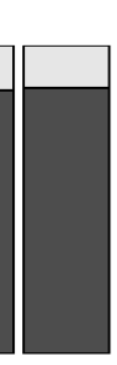

SC

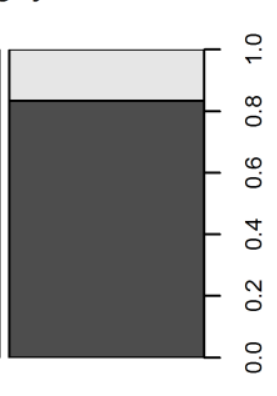

NIN

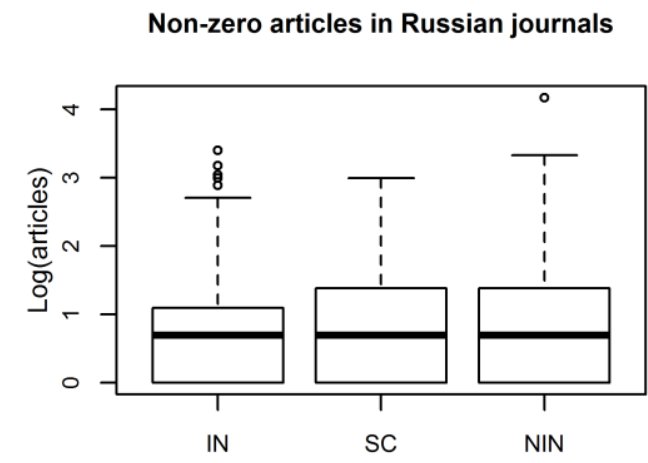

Non-zero articles in university journals

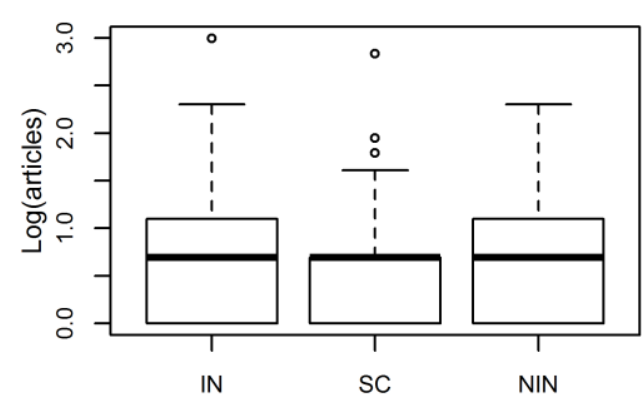

Non-zero articles in foreign journals

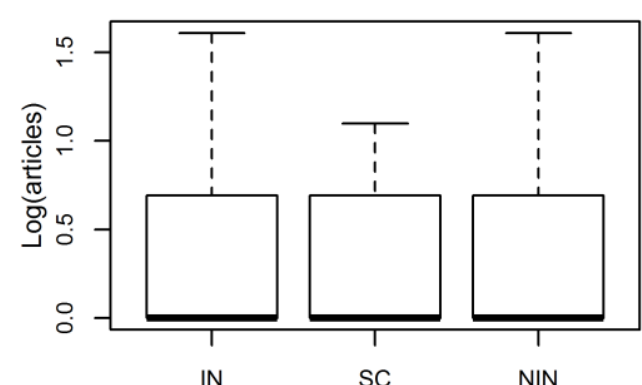

Figure 2. Probability of publishing and distribution of the number of different types of articles for inbreds (IN), silver-corded (SC), and non-inbreds (NIN).

\section{Discussion and conclusion}

This study has examined the relationship between academic inbreeding and publishing productivity among Russian faculty. The results manifest the absence of strong and robust 
evidence of the effect of academic inbreeding on the mean publishing productivity of Russian faculty. Inbreds, silver-corded faculty, and non-inbreds have approximately the same probability of publishing both articles in Russian journals, articles in journals published by their university and articles in foreign journals. It seems that these results mean that inbreds and non-inbreds in general are equally effective in publishing. The most likely explanation may be the lack of the academic inbreeding effect on the faculty's publishing productivity in terms of the number of publications. It is often the case in academic systems, such as that of Russia, in which academic inbreeding practice are deeply embedded and considered as natural. There are several characteristics of the Russian academic system that may explain the lack of effect of academic inbreeding on faculty's publishing and perhaps productivity.

The Russian academic system is characterized by high inbreeding and low mobility rates (E. Sivak \& Yudkevich, 2015). Moreover, this situation is deeply embedded in the institutional environment and is considered to be the norm. Unlike many other countries, in Russia most deans and chairs consider that hiring practices should be aimed at the university's own graduates (Horta \& Yudkevich, 2016; E. Sivak \& Yudkevich, 2015; Y. Sivak \& Yudkevich, 2009). The situation was inherited from the Soviet period: in the Soviet Union it was considered very prestigious for graduates to be hired by their own universities (at least in social sciences) instead of being redirected to other organization, and only the best students would be hired by their universities (Kuzminov \& Yudkevich, 2007). Now, although the USSR collapsed more than 20 years ago, the practice of hiring the university's own graduates is still regarded as the norm. Prestigious universities consider that they provide the best quality education and therefore hire their own graduates, as they are the best. At the same time, less prestigious universities do not have enough resources to attract graduates from better universities and have to hire their own graduates. Moreover, the academic system in Russia can be regarded as 'closed'. This means that it consists of a range of academic 
systems, with different universities having different standards of education and research transferred onto students. Thus, graduates usually fit these standards and norms best (E. Sivak \& Yudkevich, 2008). Hiring graduates also helps to reduce costs and risks related to hiring a person from outside, of whose performance little is known. This situation is reinforced by the fact that a large proportion of universities in Russia are teaching-oriented and teaching and educational performance are specific features that are difficult to measure from the outside (Godechot \& Louvet, 2008; Majcher, 2004). University administration may also expect that inbred faculty would become more committed employees who are more involved in job and better prepared for extra work, and have stronger intentions to stay and greater well-being (Lovakov, 2016).

Another characteristic of the Russian academic system is closed academic labor market. Open competition is officially obligatory in the hiring process, but in the Russian academic labor market it is a 'fiction' (Altbach et al., 2015a, 2015b). Closed labor markets usually reproduce themselves, because in those rare cases when open competition is announced, no outsiders participate in it, because they do not believe they have any chance in comparison to graduates and internal candidates of the recruiting university (Yudkevich, 2015). As Horta and Yudkevich (2016) put it, the situation is intensified by the limited rental markets, uncompetitive salaries in academia and the uneven distribution of universities by location. Low academic salaries prevent young academics from moving to other regions where there are more universities, and thus more possibilities for hiring, as their earnings are too low for property renting in another region. Moreover, low academic salaries, already uncompetitive compared to those in other sectors, make the university sector unattractive for graduates. Universities, therefore, try to involve their best students and $\mathrm{PhD}$ students in teaching and research early in their studies, without allowing them to test themselves in the external labor market. This situation stimulates academic inbreeding. 
Moreover, the absence of competition on the academic labor market leads not only to high inbreeding rates, but also to the change in the role of publishing productivity. Most studies devoted to the relationship between inbreeding and research productivity regard publications as 'signals' sent by academics to the academic community outside their institutions. Other universities take publishing productivity of candidates into account while making hiring decisions. Thus, in most countries academics who intend to change their place of work increase their short-term publishing productivity (Deville et al., 2014; Horta, 2013) and this may further explain the difference in research productivity between inbreds and noninbreds. The absence of open labor market with competition leads to the fact that publications lose their importance as each higher education institution values its own markers of success. Thus, the absence of difference in publishing productivity between inbreds and non-inbreds that we revealed may mean that in close academic systems publications are not the main criteria for comparison of inbreds and non-inbreds and it is also important to look at many other practices of their professional lives.

However, the absence of significant differences in the number of publications may not mean the absence of difference in their quality and other characteristics. For instance, it is possible that inbreds and non-inbreds have different publication strategies, which may depend on faculty orientation (towards close colleagues and the local university community, or towards the national and international communities (Horta et al., 2010)). They may differ in the pattern of collaboration and co-authorship. Future studies comparing inbreds and noninbreds need to measure not only the number but also the quality of publications and other patterns of academic activity.

The results of our analysis show that the consequences of inbreeding in Russia are not so detrimental, at least in terms of its impact on the publication productivity of academics, as is usually thought when taking into account the widespread nature of the practice. In many 
countries, various limitations, and even total prohibition, on universities hiring their own graduates are being put in place (Jacob \& Teichler, 2009; Pan, 1993). Most scholars agree that inbreeding is a harmful practice in general. Nevertheless, as the Russian academic system is currently in a period of transition, inbreeding can help many strong universities to hire the best candidates (frequently they are their own graduates) with minimal risks in the situation of information asymmetry (Horta \& Yudkevich, 2016). As far as we do not see empirical evidence of its harm in Russia, we may suppose that, in the current circumstances, there is no way to implement a total ban on inbreeding, nor any sense in doing so. Although more detailed research on the research productivity of faculty in Russia is needed, the overall conclusion from our analysis is that we cannot say that inbreeding is a very harmful practice and it should not be regarded as a priority issue for the Russian higher education system.

\section{References}

Altbach, P. G., Yudkevich, M., \& Rumbley, L. E. (2015a). Academic inbreeding: local challenge, global problem. Asia Pacific Education Review, 16(3), 317-330. http://doi.org/10.1007/s12564$015-9391-8$

Altbach, P. G., Yudkevich, M., \& Rumbley, L. E. (2015b). Academic Inbreeding: Local Challenge, Global Problem. In M. Yudkevich, P. G. Altbach, \& L. E. Rumbley (Eds.), Academic Inbreeding and Mobility in Higher Education. Global Perspectives (pp. 1-17). Palgrave Macmillan.

Bäker, A. (2015). Non-tenured post-doctoral researchers' job mobility and research output: An analysis of the role of research discipline, department size, and coauthors. Research Policy, 44(3), 634-650. http://doi.org/10.1016/j.respol.2014.12.012

Berelson, B. (1960). Graduate Education in the United States. New York: McGraw Hill.

Bondarenko, N., Gokhberg, L., Zabaturina, I., Kovaleva, N., Kuznetsova, V., Ozerova, O., Pinskaya, M. , Podolskiy, O., Ponomareva, A., Rylko, E., Schugal, N. (2017). Indicators of Education in the Russian Federation: 2017. Data Book. Moscow: HSE. 
Chan, D. (2009). So why ask me? Are self-report data really that bad? In C. E. Lance \& R. J. Vandenberg (Eds.), Statistical and methodological myths and urban legends: Doctrine, verity and fable in the organizational and social sciences (pp. 309-336). New York: Routledge.

Cruz-Castro, L., \& Sanz-Menéndez, L. (2010). Mobility versus job stability: Assessing tenure and productivity outcomes. Research Policy, 39(1), 27-38. http://doi.org/10.1016/j.respol.2009.11.008

Deville, P., Wang, D., Sinatra, R., Song, C., Blondel, V. D., \& Barabási, A.-L. (2014). Career on the move: geography, stratification, and scientific impact. Scientific Reports, 4, 4770. http://doi.org/10.1038/srep04770

Dutton, J. K. (1980). The impact of Inbreeding and Immobility on the Professional Role and Scholarity Performance of Academic Scientists. Boston. Retrieved from http://eric.ed.gov/?id=ED196714

Eells, W. C., \& Cleveland, A. C. (1935). The Effects of Inbreeding. The Journal of Higher Education, 6(6), 323-328.

Eliot, C. W. (1908). University Administration. Boston: Houghton Mifflin.

Fernández-Zubieta, A., Geuna, A., \& Lawson, C. (2015). What do We Know of the Mobility of Research Scientists and Impact on Scientific Production. In A. Geuna (Ed.), Global Mobility of Research Scientists (pp. 1-34). Academic Press. Retrieved from http://ssrn.com/abstract=2611203

Fox, M. F. (1983). Publication Productivity among Scientists: A Critical Review. Social Studies of Science, 13(2), 285-305. http://doi.org/10.1177/030631283013002005

Fursov, K., Roshina, Y., \& Balmush, O. (2016). Determinants of Research Productivity: An Individual-level Lens. Foresight and STI Governance, 10(20), 44-56. http://doi.org/10.17323/1995-459X.2016.2.44.56

Godechot, O., \& Louvet, A. (2008). Academic Inbreeding: An Evaluation. Retrieved from http://www.booksandideas.net/Academic-Inbreeding-An-Evaluation.html Gorelova, O., \& Yudkevich, M. (2015). Academic Inbreeding: State of the Literature. In M. Yudkevich, P. G. Altbach, \& L. E. Rumbley (Eds.), Academic Inbreeding and Mobility in 
Higher Education. Global Perspectives (pp. 17-45). Palgrave Macmillan.

Hargens, L. L., \& Farr, G. M. (1973). An Examination of Recent Hypotheses About Institutional Inbreeding. The American Journal of Sociology, 78(6), 1381-1402.

Horta, H. (2013). Deepening our understanding of academic inbreeding effects on research information exchange and scientific output: new insights for academic based research. Higher Education, 65(4), 487-510. http://doi.org/10.1007/s10734-012-9559-7

Horta, H., Veloso, F., \& Grediaga, R. (2010). Navel gazing: Academic inbreeding and scientific productivity. Management Science, 56(3), 414-429. http://doi.org/10.1287/mnsc.1090.1109

Horta, H., \& Yudkevich, M. (2016). The role of academic inbreeding in developing higher education systems: Challenges and possible solutions. Technological Forecasting and Social Change, 113, 363-372. http://doi.org/10.1016/j.techfore.2015.06.039

Inanc, O., \& Tuncer, O. (2011). The effect of academic inbreeding on scientific effectiveness. Scientometrics, 88(3), 885-898. http://doi.org/10.1007/s11192-011-0415-9

Jacob, A. K., \& Teichler, U. (2009). The Changing Employment and Work Situation of the Academic Profession in Germany. In The Changing Academic Profession over 1992-2007: International, Comparative, and Quantitative Perspectives (pp. 253-269). Higashi-Hiroshima: Research Institute for Higher Edcuation, Hiroshima University.

Klemenčič, M., \& Zgaga, P. (2015). Slovenia: The Slow Decline of Academic Inbreeding. In M. Yudkevich, P. G. Altbach, \& L. E. Rumbley (Eds.), Academic Inbreeding and Mobility in Higher Education. Global Perspectives. Palgrave Macmillan.

Kuzminov, Y. I., \& Yudkevich, M. (2007). Universitety v Rossii i v Amerike: razlichiya akademicheskikh konventsiy [Universities in Russia and the US: Differences in Academic Concepts]. Voprosy Obrazovaniya / Educational Studies. Moscow, (4), 141-158.

Larivière, V., Archambault, É., Gingras, Y., \& Vignola-Gagné, É. (2006). The place of serials in referencing practices: Comparing natural sciences and engineering with social sciences and humanities. Journal of the American Society for Information Science and Technology, 57(8), 997-1004. http://doi.org/10.1002/asi.20349

Loeys, T., Moerkerke, B., De Smet, O., \& Buysse, A. (2012). The analysis of zero-inflated count data: 
Beyond zero-inflated Poisson regression. British Journal of Mathematical and Statistical Psychology, 65(1), 163-180. http://doi.org/10.1111/j.2044-8317.2011.02031.x

Lovakov, A. (2016). Antecedents of organizational commitment among faculty: an exploratory study. Tertiary Education and Management, 22(2), 149-170. http://doi.org/10.1080/13583883.2016.1177583

Majcher, A. (2004). Mobility and academic career: Reforming the "inbreeding" system in Centraland Eastern Europe. In T. Gabaldón, H. Horta, D. M. Meyer, \& J. B. Pereira-Leal (Eds.), Career Paths and Mobility of Researchers in Europe (pp. 158-161). Lisbon.

McGee, R. (1960). The Function of Institutional Inbreeding. The American Journal of Sociology, 65(5), 483-488.

Morichika, N., \& Shibayama, S. (2015). Impact of inbreeding on scientific productivity: A case study of a Japanese university department. Research Evaluation, 24(2), 146-157. http://doi.org/10.1093/reseval/rvv002

Musselin, C. (2004). Towards a European Academic Labour Market? Some Lessons Drawn from Empirical Studies on Academic Mobility. Higher Education, 48(1), 55-78. http://doi.org/10.1023/B:HIGH.0000033770.24848.41

Pan, S. (1993). A study of faculty inbreeding at eleven land-grant universities. Iowa State University. Paul-Hus, A., Bouvier, R. L., Ni, C., Sugimoto, C. R., Pislyakov, V., \& Larivière, V. (2015). Forty years of gender disparities in Russian science: a historical bibliometric analysis. Scientometrics, 102(2), 1541-1553. http://doi.org/10.1007/s11192-014-1386-4

Pelz, D. C., \& Andrews, F. M. (1966). Scientists in organizations. New York: Wiley.

R Core Team (2016). R: A language and environment for statistical computing. R Foundation for Statistical Computing, Vienna, Austria. Retrieved from http://www.r-project.org/

Roleda, R., Bombongan, D., Tan, R. R., Roleda, L., \& Culaba, A. (2014). Probing the Outliers: Predictors of Research Productivity at DLSU. In DLSU Research Congress (pp. 1-8). De La Salle University, Manila, Philippines.

Sato, A. (1992). The Scholarly Productivity of Inbred and Noninbred Faculty in Schools of Nursing with Graduate and Undergraduate Programs. University of Utah. 
Sivak, E., \& Yudkevich, M. (2008). «Zakrytaya» akademicheskaya sreda i lokal'nye akademicheskie konventsii [«Closed» Academic Environment and Local Academic Conventions]. ForesightRussia, 2(4), 32-41.

Sivak, E., \& Yudkevich, M. (2015). Academic Immobility and Inbreeding in Russian University Sector. In M. Yudkevich, P. G. Altbach, \& L. E. Rumbley (Eds.), Academic Inbreeding and Mobility in Higher Education. Global Perspectives (pp. 130-155). Palgrave Macmillan.

Sivak, Y., \& Yudkevich, M. (2009). Akademicheskiy inbriding: za i protiv [Academic Inbreeding: Pro and Contra]. Voprosy Obrazovaniya / Educational Studies. Moscow, (1), 170-187. http://doi.org/10.17323/1814-9545-2009-1-170-187

Smyth, R., \& Mishra, V. (2014). Academic inbreeding and research productivity and impact in Australian law schools. Scientometrics, 98(1), 583-618. http://doi.org/10.1007/s11192-013$1052-2$

Soler, M. (2001). How inbreeding affects productivity in Europe. Nature, 411(6834), 132-132. http://doi.org/10.1038/35075637

Sologub, I., \& Coupé, T. (2015). Academic Inbreeding in Ukraine. In M. Yudkevich, P. G. Altbach, \& L. E. Rumbley (Eds.), Academic Inbreeding and Mobility in Higher Education. Global Perspectives. Palgrave Macmillan.

Sterligov, I., \& Savina, T. (2016). Riding with the Metric Tide: "Predatory" Journals in Scopus. Higher Education in Russia and Beyond, 1(7), 9-12.

Wyer, J. C., \& Conrad, C. F. (1984). Institutional Inbreeding Reexamined. American Educational Research Journal, 21(1), 213-225.

Yudkevich, M. (2014). The Russian University: recovery and rehabilitation. Studies in Higher Education, 39(8), 1463-1474. http://doi.org/10.1080/03075079.2014.949537

Yudkevich, M. (2015). The University Sector in Russia: Young Romantics and Losers Welcome? In M. Yudkevich, P. G. Altbach, \& L. E. Rumbley (Eds.), The Future of the Academic Profession: Young Faculty in International Perspective (pp. 227-252).

Yudkevich, M., Kozmina, Y., Sivak, E., Bain, O., \& Davydova, I. (2013). Changing Academic Profession: Russia Country Report. Moscow. 
Zeileis, A., Kleiber, C., \& Jackman, S. (2008). Regression Models for Count Data in R. Journal of Statistical Software, 27(8), 1-25. http://doi.org/10.18637/jss.v027.i08 